\title{
Development of a Medical Error Scale for Nursing Students: a Methodological Study
}

\author{
Ilknur Kahriman ${ }^{1}$ (D), Havva Ozturk1 ${ }^{10}$ \\ ${ }^{1}$ Karadeniz Technical University, Faculty of Health Sciences, Nursing Department, Trabzon, Turkey. \\ Correspondence Author: Ilknur Kahriman \\ E-mail: ilknurkahriman@hotmail.com \\ Received: 19.01.2018 Accepted: 10.03.2018
}

\begin{abstract}
Objective: The purpose of this study was to develop the Medical Error Scale (MES) for the student nurses

Methods: This study was a methodological research. The study was conducted with 662 student nurses to develop a Medical Error Scale for student nurses. The scale development study was carried out in the nursing departments of the health sciences faculty of two universities; one in istanbul and one in Trabzon. The data were collected with a questionnaire consisting of 6 questions about the demographic characteristics of the students and a draft scale including 94 items. In the analysis of the data, frequency, percentage, mean tests, confirmatory and exploratory factor analyses' tests were used.

Results: Content Validity Index of the scale was 0.82, Cronbach's Alpha was 0.94, Spearman-Brown was 0.93,Guttman coefficient were 0.92, the upper and lower $27 \%$ test was -44.42 and $p=0.000$, and item-total item correlation values ranged from 0.36 to 0.68 . The scale had seven subscales according to exploratory factor analysis. The results of confirmatory factor analysis were chi-square/degree of freedom 3.01, RMSEA=0.055, CFI= $0.97, \mathrm{NNFI}=0.97$ and NFI= 0.96 and the scale showed a good agreement with the subscales.

Conclusion: The scale was a valid and reliable tool to collect data on whether student nurses acted carefully or made medical errors during their patient-related practices.

Keywords: Nurse, Student, Scale, Medical Error, Malpractices
\end{abstract}

\section{INTRODUCTION}

In recent years, quality service delivery in national and international health care and patient safety has become an increasingly important and updated topic. Therefore, the prevention or reduction of medical errors and medical malpractices as much as possible, which is an important criterion for patient safety, should be considered as a priority $(1,2)$. In this respect, all healthcare workers, as well as anyone who provides direct or indirect services to the patient, are responsible for the prevention or reduction of medical errors (3).

When the studies on this topic were examined, it was seen that the vast majority of the studies were carried out by health professionals. However, medical malpractices can be carried out not only by health professionals but also by nursing students (4, 5). In some countries, as in the case of our country to close the nurse shortage in clinics, especially senior students are hired to work part-time and usually night shifts. This situation may cause students to put the safety of the patient in jeopardy by performing malpractices. Despite the legal and ethical dimensions of such an appointment or responsibility, this is an undeniable fact. The fact that students are performing an application on a patient without the supervision of the academicians, nurses or counselor nurses and that the patient is severely damaged as a result of the application can cause the student, the instructor, the nursing school and the institution to face the legal problems (6). In addition, medical malpractices can lead to an increase in financial burden due to the prolonged length of hospitalization time of patients, adverse events/ cases such as disability, death in patients, and compensation cases. For these reasons, as Alcan et al., (2012) pointed out that unforeseen events and errors that cause patient safety violations should be identified and analyzed with the aim of preventing errors in advance. Risks must be reduced to prevent errors by predicting situations that put patient safety in jeopardy. Moreover, risky situations and errors must be reported, the causes must be revealed, the proposals for the solution of the problem must be determined and lessons must be drawn from the events $(2,7)$. In this direction, as Akgün and Al-Assaf (2007) also indicated that it was necessary to collect data and evidence with systematic approaches to demonstrate why medical errors arise to develop strategies to solve the problems in the health care system (8). The studies by Rodrigue et al., (2012) and Mira et al., (2015) revealed that the number of studies on what the medical and nursing students knew and what their attitudes were towards adverse events was very limited $(9,10)$. In addition, as Vaismoradi et al., (2011) indicated that the curricula and instructional strategies of nursing students or their perspectives on their training should be assessed to strengthen them so as to ensure the safety of 
service (11). For this reason, it is important to develop valid and reliable scales that will make it easier for nursing students to see whether they are careful about medical errors or what mistakes they can make. Besides, it will be possible to determine in which areas students can make more errors with these scales or tools, take precautions towards risky areas, make measurements at periodical intervals and contribute to the solution of problems. In this context, the investigations of the measurement tools related to medical malpractices for students have reported that Tabbassum et al., (2015) developed a tool to measure medical errors for nursing students, but only its content validity was tested (12). Mira et al., (2015) also developed a measurement tool whose validity and reliability analyses were tested and it evaluated the knowledge and attitudes of medical and nursing students about patient safety during clinical trainings in five countries (10). In the study of Mansour (2015), a Likert-type scale was developed not related to individual medical errors but with the aim of evaluating the perceptions of nursing students about their awareness, skills and attitudes towards the patient safety education by performing exploratory factor analysis (13). As can be seen, a reliable and validated tool to deal with the medical errors or malpractices that can be done by nursing students was not found in the literature. As a result, it was reported that there was a limited number of studies on medical errors related to nursing students with large populations who are risk bearing and serving patients and that there is a gap in the literature concerning to the subject $(14,15)$.

In this context, this study aimed to develop a valid and reliable medical error scale (MES) in order to investigate whether nursing students were performing medical malpractices related to their diagnosis, treatment and care practices during clinical applications, to identify common errors, types and causes of errors, whether students were careful about medical errors or medical malpractices, and to facilitate the identification of the areas where they were likely to have malpractices.

\section{METHODS}

\subsection{Type of Study}

This study was a methodological one as the Medical Error Scale (MES) was developed for the student nurses.

\subsection{The Universe and Sampling of the Study}

The universe of the study consisted of 1561 students studying in the nursing departments of two universities and sampling composed of 662 students selected by a simple random sampling method. In the factor analysis, 50 is considered very poor, 100 poor, 200 fair, 300 good, 500 very good and 1000 excellent for a sufficient sample size (16). For the test-retest study conducted within the scope of validity and reliability, 52 nursing students in a different university were included in the sampling. For the test-retest analysis, the sample should be at least 50 people (17).

\subsection{Location and Characteristics of the Research}

The scale development study was carried out in the nursing departments of the health sciences faculty of two universities; one in İstanbul and one in Trabzon.

\subsection{Ethical Considerations}

Written permission was obtained from the rectors and deans of the two universities to conduct the research on 15 July 2013 and 20 August 2013. The research ethics committee approval was received from the Ethics Committee of NonInterventional Clinical Investigations of Haliç University on 09 September, 2013. Protocol number 06. In addition, nurse students' voluntary participation was ensured.

\subsection{Data Collection Tools}

In the scale development study, an information form and the Draft Medical Error Scale were used. The information form includes 6 questions about the nurses' age, gender, marital status, the type of high school they graduated from, and the names and classes of the universities they were studying in. The draft medical error scale was designed to determine whether student nurses performed patient applications safely during clinical practices, whether they made malpractices or medical errors or they were cautious about medical errors. It was developed by the researchers in the light of literature (18-30) under the following subheadings; care practices, medication administration, falling, infection and communication. In addition, this draft scale was prepared as a 5-point Likert-type scale consisting of 94 items which were evaluated as always (5), usually (4), sometimes (3), rarely (2), never (1).

\subsection{Data Collection Process}

During the first phase of the study, the data of face validity of the draft scale established with 94 items by Oztürk ve Kahriman with the help of the literature were obtained by interviewing 3 nurses through face-to-face interviews, and both the face and the content validity data were received by hand or by e-mails. For content validity, a guideline was submitted to the experts explaining the Lawshe technique, which introduced the scale and would be used for content validity. After the content validity process, the data regarding the exploratory (EFA), and confirmatory factor analysis (CFA) under the scope of the construct validity and the reliability analyses of the 85item draft scale were received by hand from the second, third, and fourth - year nursing students at two universities, one in Trabzon and one in Istanbul by the researchers. The students were explained the aim of the study and how they should fill the scale. Afterwards, the data obtained from the students were entered into the statistical programs and the EFA, CFA and the reliability analyses were carried out. After the EFA and CFA analysis, the test-retest data, which is a reliability test, was conducted with a separate sampling including 52 student nurses studying at a university in Erzurum after the aim and the application process were explained. The students were asked to use nicknames and the 36-item scale was applied and received by hand with an interval of two weeks. 


\subsection{Statistical Analysis}

Before all the tests carried out within the scope of the study, the central and prevalence criteria of the normal distribution of the data were checked and the Kolmogrov-Smirnov test was performed.

Percentage, mean tests and EFA and CFA were conducted for the validity analysis of MES. EFA was performed with KaiserMeyer-Olkin (KMO) and Bartlett test, anti-image correlation, Principal Components Analysis and Varimax Rotation. Chisquare, $\mathrm{X} 2$, RMSEA, CFI, NNFI, NFI tests were used for CFA. Besides, t-test and regression analysis were also used. For reliability analysis, Cronbach Alpha, item-total correlation tests and test-retest were performed.

Limitations of the study;

The limitation of the research was that it was carried out through the opinions of second, third, and fourth - year nursing students at two universities in Turkey. Another limitation is the use of a sample set of the exploratory factor analysis for confirmatory factor analysis.

\section{RESULTS}

According to the demographic characteristics of the student nurses, the average age of the students was $20.66 \pm 1.78$ years. $60.9 \%$ (403) of them were studying at Karadeniz Technical University, Faculty of Health Sciences, Nursing Department and $39.1 \%$ (259) of them were studying at Marmara University Faculty of Health Sciences, Nursing Department. $81.7 \%(541)$ of them were female, $18.3 \%$ (121) were male, $97.4 \%$ were single and $2.6 \%$ (17) were married. $54.5 \%$ (361) were second-year students, $22.4 \%$ (148) were third-year students and $23.1 \%$ (153) were fourth-year students. $53.8 \%$ (356) were Anatolian/Super/Science High School, 35\% (232) were Standard High School, $11.2 \%$ (74) were Vocational Health High School and other high school graduates (Table 1).

Table 1. The demographic characteristics of the student nurses

\begin{tabular}{|l|l|l|}
\hline Demographic characteristics & Mean & SD \\
\hline Age & 20.66 & 1.78 \\
\hline University & $\mathrm{n}$ & $\%$ \\
\hline KTU Faculty of Health Sciences & 403 & 60.9 \\
MU Faculty of Health Sciences & 259 & 39.1 \\
\hline Gender & & \\
Female & 541 & 81.7 \\
Male & 121 & 18.3 \\
\hline Marital Status & & \\
Single & 645 & 97.4 \\
Married & 17 & 2.6 \\
\hline Class & & \\
second-year students & 361 & 54.5 \\
third-year students & 148 & 22.4 \\
fourth-year students & 153 & 23.1 \\
\hline Graduated sSchool & & \\
Anatolian/Super/Science High School & 356 & 53.8 \\
Standard High School & 232 & 35.0 \\
Vocational Health and Other High School & 74 & 11.2 \\
\hline Total & 662 & 100.0 \\
\hline
\end{tabular}

\subsection{Face Validity}

In terms of face validity of the draft scale, it was submitted to three student nurses and their opinions were requested to determine whether it was understandable, easy to read, expressed properly, accurately, clearly, whether the students were bored during filling, whether its statements were long, and how much time was spent. Afterwards, experts' opinions were asked for both face and content validity, and each item was evaluated by them. 6 items in the scale were improved to be more comprehensible.

\subsection{Content Validity}

Content validity means to what extent the test or scale items, specified as the sample, represent the conceptual main mass for a specific purpose. In other words, the more selected sample items represent the conceptual main mass, the more content validity they have (Şencan, 2005). Lawshe technique was used for content validity of a study and it consisted of setting up field expert groups, preparing candidate scale forms, receiving expert opinions and content indexes for the items, and formulating the form (31). In this direction, a total of 15 specialists who had worked as nurses and managers for many years in the fields of Nursing Fundamentals, Internal Diseases Nursing, Surgical Diseases Nursing, Obstetrics and Gynecology Nursing, Pediatrics Nursing, Nursing Management were requested to give their opinions. The experts evaluated each item as 'Necessary/ Appropriate', 'Need to be Improved' or 'Unnecessary/ Inappropriate' to assess the suitability of the materials for the purpose and conceptual structure. From the 94-item scale prepared as a draft, 9 items were excluded in line with the opinions of the experts and finally the scale was formed with 85 items. With the exclusion of 9 items due to their minimum value of the Content Validity Ratio (CVR) which was under 0.49 at $\alpha=0.05$ significance level, the ultimate Content Validity Index (CVI) was determined as 0.82 .

\subsection{Construct Validity}

Exploratory (EFA) and confirmatory (CFA) factor analyses were conducted to test the construct validity of the MES. Principal Components Analysis and Varimax Rotation Method with Kaiser Normalization were used for EFA. While the KMO (Kaiser - Meyer-Olkin) value of the 85 -item draft scale was found as 0.935, the Bartlett test was $\chi^{2}=12467.131$ and $p=$ 0.000 and anti-image correlation values were between 0.837 and 0.965 .

In Rotated Component Matrix analysis for EFA, 7 rotations were performed. Twenty-six items $(4,5,7,8,17,24,26,27,2$ $9,30,32,33,34,40,41,50,51,52,53,71,72,73,75,77,81,83)$ in the first rotation, 9 items $(85,35,74,76,13,21,31,949)$ in the second, 4 items $(48,37,6,12)$ in the third, 2 items $(11,25)$ in the fourth, 1 item $(10)$ in the fifth, 3 items $(38,14,28)$ in the sixth, and 4 items $(22,23,36,39)$ in the seventh rotation were excluded since their loadings ( 49 items) were under 0.45 . The scale was made up of 7 sub-dimensions and 36 items and it was free from overlapping items. The factor load values of the scale were between 0.559 and 0.827 . 
Table 2. The mean values of factor items of MES and factor load values distributions

\begin{tabular}{|l|l|l|l|l|l|l|l|}
\hline Factor Name & $\begin{array}{l}\text { Variance } \\
\%\end{array}$ & Items & Min. & Max & Mean & SD & $\begin{array}{l}\text { Factor load } \\
\text { value }\end{array}$ \\
\hline F1 - Falling & 13.45 & $59-66$ & 1.38 & 5.0 & 4.20 & 0.69 & $0.602-.715$ \\
\hline $\begin{array}{l}\text { F2 - Blood and Blood } \\
\text { Product Transfusion }\end{array}$ & 11.92 & $42-47$ & 2.0 & 5.0 & 4.62 & 0.54 & $0.686-.827$ \\
\hline F3 - Patient Transfer & 8.67 & $54-58$ & 1.0 & 5.0 & 4.11 & 0.79 & $0.559-.754$ \\
\hline $\begin{array}{l}\text { F4-Medication } \\
\text { Administration }\end{array}$ & 8.25 & $15,16,18-20$ & 1.0 & 5.0 & 3.89 & 0.74 & $0.640-.709$ \\
\hline F5-Communication & 8.15 & $78-80,82,84$ & 1.6 & 5.0 & 4.47 & 0.60 & $0.623-.700$ \\
\hline F6- Infection & 6.92 & $67-70$ & 2.5 & 5.0 & 4.56 & 0.52 & $0.598-.768$ \\
\hline F7-Care Practices & 5.17 & $1-3$ & 2.7 & 5.0 & 4.30 & 0.46 & $0.618-.807$ \\
\hline Total & 62.55 & & & & & & \\
\hline
\end{tabular}

Table 3. Distribution of the items and their factor loadings according to the subscales of MES

\begin{tabular}{|c|c|c|}
\hline \multicolumn{2}{|c|}{$\begin{array}{l}\text { Item } \\
\text { Number Subscales of MES }\end{array}$} & $\begin{array}{l}\text { Factor } \\
\text { loads }\end{array}$ \\
\hline \multicolumn{3}{|c|}{ Falling } \\
\hline 62 & $\begin{array}{l}\text { I tell the patient's companion that they should inform the } \\
\text { nurse when they are leaving the patient alone. }\end{array}$ & 0.715 \\
\hline 65 & $\begin{array}{l}\text { I ensure that patient rooms or corridor floors are dried if } \\
\text { they are wet. }\end{array}$ & 0.696 \\
\hline 63 & $\begin{array}{l}\text { I put the call button somewhere the patient can easily } \\
\text { use. }\end{array}$ & 0.685 \\
\hline 66 & I often visit the patients who have a risk of falling. & 0.678 \\
\hline 60 & $\begin{array}{l}\text { I tell the patient that s/he should inform a nurse when s/ } \\
\text { he wants to stand up. }\end{array}$ & 0.673 \\
\hline 64 & I remove unused materials out of the patient's room. & 0.655 \\
\hline 61 & $\begin{array}{l}\text { For agitated patients, I place cushions on the side of the } \\
\text { bed. }\end{array}$ & 0.649 \\
\hline 59 & I lock beds and wheelchairs if they are not used. & 0.602 \\
\hline \multicolumn{2}{|c|}{ Blood and Blood Product Transfusion } & \\
\hline 45 & $\begin{array}{l}\text { I apply blood and blood products according to the } \\
\text { technique. }\end{array}$ & 0.827 \\
\hline 44 & $\begin{array}{l}\text { Before applying blood and blood products, I check } \\
\text { their expiration dates. }\end{array}$ & 0.795 \\
\hline 43 & $\begin{array}{l}\text { I control the label information of the product before } \\
\text { applying blood and blood products. }\end{array}$ & 0.791 \\
\hline 46 & $\begin{array}{l}\text { I make sure of the blood type of the patient before } \\
\text { using blood and blood products. }\end{array}$ & 0.785 \\
\hline 47 & $\begin{array}{l}\text { I observe the patient for possible complications after } \\
\text { the application of blood and blood products. }\end{array}$ & 0.738 \\
\hline 42 & $\begin{array}{l}\text { I prepare blood and blood products according to the } \\
\text { procedures. }\end{array}$ & 0.686 \\
\hline \multicolumn{2}{|c|}{ Patient Transfer } & \\
\hline 56 & $\begin{array}{l}\text { I confirm that the patient is not being transferred } \\
\text { alone. }\end{array}$ & 0.754 \\
\hline 55 & $\begin{array}{l}\text { I always monitor my patients while they are being } \\
\text { transferred. }\end{array}$ & 0.741 \\
\hline 57 & I make sure that the patient is not discharged alone. & 0.697 \\
\hline 54 & $\begin{array}{l}\text { I ensure the transfer of the patient according to the } \\
\text { protocol (with a stretcher / a wheelchair). }\end{array}$ & 0.668 \\
\hline 58 & $\begin{array}{l}\text { I check the availability of the care equipment and } \\
\text { devices before transfer. }\end{array}$ & 0.559 \\
\hline \multicolumn{2}{|c|}{ Medication Administration } & \\
\hline 20 & $\begin{array}{l}\text { I administer medication after I learn its effects, } \\
\text { interaction and side effects. }\end{array}$ & 0.709 \\
\hline
\end{tabular}

\begin{tabular}{|c|c|c|}
\hline 15 & $\begin{array}{l}\text { I give the patient's oral medication or be near him/her } \\
\text { until s/he takes it. }\end{array}$ & 0.705 \\
\hline 16 & $\begin{array}{l}\text { I do not leave the medication with the patient so that } \\
\text { s/he can take or apply it. }\end{array}$ & 0.679 \\
\hline 18 & $\begin{array}{l}\text { After the medication I monitor the patient for } \\
\text { positive/adverse effects. }\end{array}$ & 0.675 \\
\hline 19 & $\begin{array}{l}\text { I do not administer medication without checking its } \\
\text { expiration date. }\end{array}$ & 0.640 \\
\hline \multicolumn{3}{|c|}{ Communication } \\
\hline 78 & I clarify unclear and potentially problematic orders. & 0.700 \\
\hline 79 & $\begin{array}{l}\text { I write down any information related to the } \\
\text { patient's treatment in the nurses' observation } \\
\text { chart. }\end{array}$ & 0.673 \\
\hline 84 & $\begin{array}{l}\text { I record the name and surname, date and time of } \\
\text { the physician instructing verbally/on the telephone. }\end{array}$ & 0.669 \\
\hline 82 & $\begin{array}{l}\text { I inform the physicians/ healthcare workers about } \\
\text { the results of emergency critical tests. }\end{array}$ & 0.651 \\
\hline 80 & $\begin{array}{l}\text { I provide information on the patient's care and } \\
\text { outcomes at shift changes. }\end{array}$ & 0.623 \\
\hline \multicolumn{3}{|c|}{ Infection } \\
\hline 68 & I put on and take off the gloves in due form. & 0.768 \\
\hline 69 & $\begin{array}{l}\text { I wash my hands and change the gloves from one } \\
\text { patient to another. }\end{array}$ & 0.750 \\
\hline 67 & $\begin{array}{l}\text { I wash my hands properly before and after the } \\
\text { practice. }\end{array}$ & 0.671 \\
\hline 70 & $\begin{array}{l}\text { I use materials and products exclusively for each } \\
\text { patient. }\end{array}$ & 0.598 \\
\hline \multicolumn{3}{|c|}{ Care Practices } \\
\hline 2 & $\begin{array}{l}\text { I check the local effects of the care practices that I } \\
\text { apply. }\end{array}$ & 0.807 \\
\hline 3 & $\begin{array}{l}\text { I check the systemic effects of the care practices } \\
\text { that I apply. }\end{array}$ & 0.725 \\
\hline 1 & $\begin{array}{l}\text { I verify the patient's identity for practices that I will } \\
\text { perform. }\end{array}$ & 0.618 \\
\hline
\end{tabular}

In the scree-plot graph of the scale, the slope plateaued after the seventh point. This cut off point also supported the fact that the scale had 7 subscales (16) These 7 subscales accounted for $62.55 \%$ of the total variance of the scale together; the first subscale accounted for $13.45 \%$, the second subscale $11.92 \%$, the third subscale $8.67 \%$, the fourth subscale $8.25 \%$, the fifth subscale $\% 8.15$, the sixth subscale $(6.92 \%)$, and the seventh subscale $(5.17 \%)$ (Table 2). Factors were named after this step. The names of the selected factors/ scales were chosen from meaningful, expressive and well-known words, and the comments and names of factors were written in accordance with the theoretical basis (32).

The factor structure of the 36-item MES was tried to be confirmed with the CFA. For CFA, firstly, the items with nonsignificant $t$-values were examined, and it was determined that all the $\mathrm{R}$ coefficients and $\mathrm{t}$-values of 36 items were significant and the model (factorial structure) was confirmed. The path diagram was presented in Figure 1.

Fit indices for MES's CFA are chi-square $\left(\chi^{2}\right)=1766.95$, chisquare/ degree of freedom $\left(x^{2} / \mathrm{df}\right)=3.01$, Root Mean Square Error of Approximation (RMSEA) $=0.055$, Comparative Fit 
Index $(\mathrm{CFI})=0.97$, Non-Normed Fit Index $(\mathrm{NNFI})=0.97$, Normed Fit Index $(\mathrm{NFI})=0.96$. When the coefficients indicating the relationship between the observed variables of the model showing the factorial structure of the scale and the factors were examined, it was concluded that all the coefficients were high. When the fit statistics calculated with the CFA was taken into consideration, the previously determined 7 factor-structure was generally determined to comply with the collected data.

To test the validity of the scale, the item-total correlation test which is an internal consistency test and an item discrimination procedure was performed, and for upper and

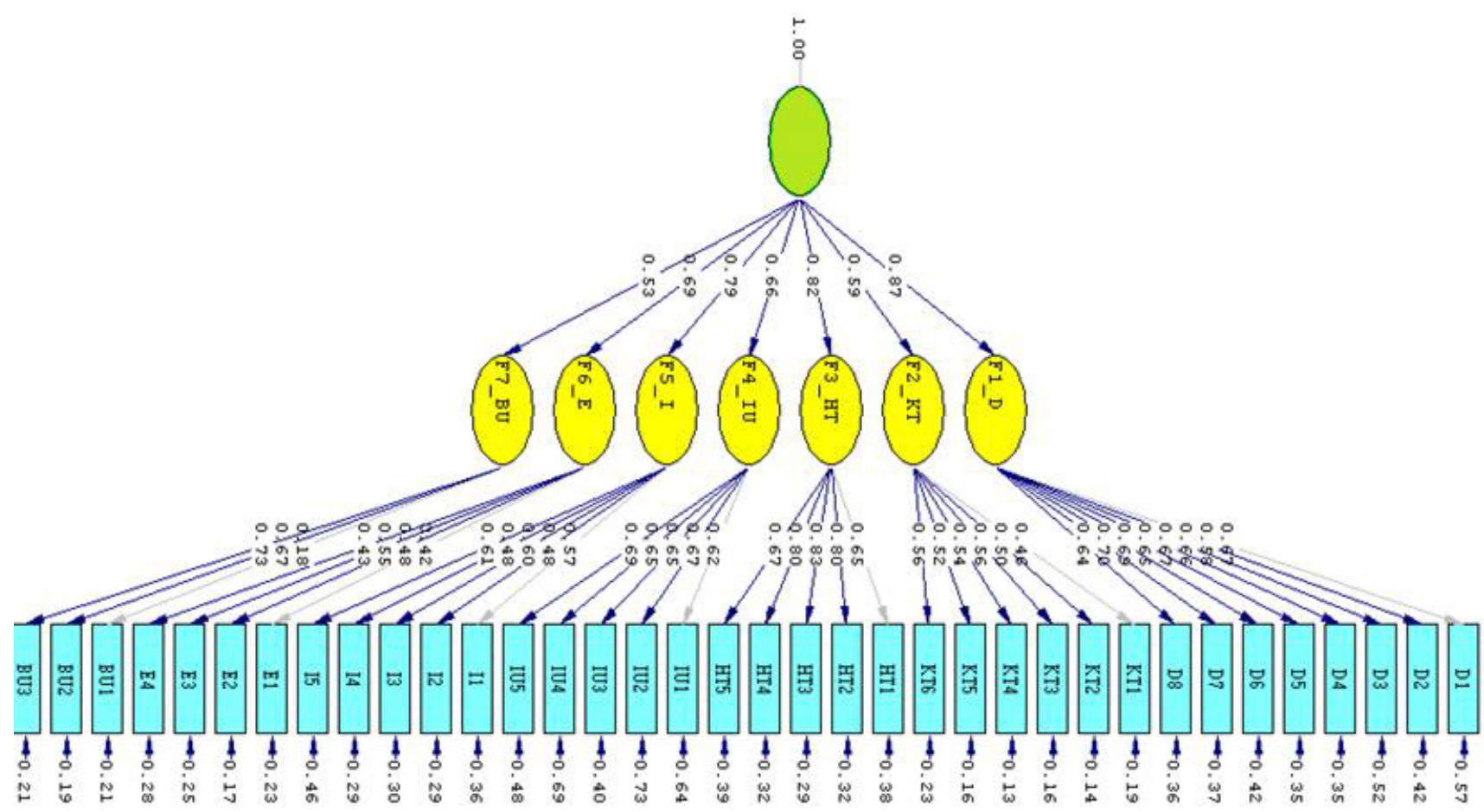

Figure 1. Path diagram for MES. $X^{2}=1766.95, X^{2} / d f=3.01, R M S E A=0.055, C F I=0.97, N N F I=0.97, N F I=0.96 . M E S=$ Medical Error Scale, $F=F a l l i n g, B T=B l o o d$ and Blood Products Transfusion, $P T=$ Patient Transfer, MA=Medication Administration, $C=$ Communication, $I=I n f e c t i o n, C P=C a r e$ Practices.

lower $27 \%$ quartiles the independent t-test was analyzed. Since the item-total correlation test is also a reliability test, it was presented within the scope of reliability tests. The t-test results for the upper and lower $27 \%$ quartiles of the scale were $\mathrm{t}=-44.427$ for total; $\mathrm{t}=-26.386$ for $\mathrm{F} 1, \mathrm{t}=-16.729$ for $F 2, t=-28.388$ for $F 3, t=-20.005$ for $F 4, t=-19.540$ for $F 5, t=-19.310$ for $F 6, t=-17.010$ for $F 7$, and $p$ values were statistically significant for each $(p=0.000)$.

\subsection{Reliability Analysis}

Cronbach Alpha, Spearman Brown and Guttman tests were tested to check the internal consistency of the draft scale within the scope of reliability. In addition, item-total correlation test which analyses both reliability and validity was performed. Test-retest analysis was used to determine the time-invariance of the scale.

The total Cronbach Alpha, Spearman-Brown, and Gutmann values of the scale were $0.94,0.93$, and 0.92 , respectively. The Cronbach Alpha values for the subscales ranged from 0.71 to 0.91 , while the Spearman Brown values ranged from 0.70 to 0.89 and the Gutmann value was between 0.70 and 0.90 .
After these analyses, item - total item correlation values, which is also a substance analysis or substance discrimination process used for testing the internal consistency, reliability and validity of the scale, were found between 0.365 and 0.684 and significant $(p=0.000)$. In addition, in the sub-factors dimension, item-total correlation values were determined as 0.568-0.647 for F1, 0.504-0.555 for F2, 0.636-0.684 for F3, 0.485-0.556 for F4, 0.537-0.620 for F5, 0.511-0.561 for F6, 0.365-0.562 for F7, $p=0.000$ ) and they were significant.

According to the test and re-test correlation values in the total of MES, there was a high positive correlation between the first and last application scores $(r=0.72)$ and this correlation was statistically significant $(p=0.000)$. In addition, there was no statistically significant difference between the two measurement scores $(p=0.482)$ in the comparison of these two application scores of the MES.

\subsection{Evaluation of the Scale}

The subscales of the scale, which was finalized with 36 items were as follows; Factor 1 - Falling (F1) 8 items (between 59 and 66); Factor 2 - Blood and Blood Transfusion (F2) 6 items (42-47); Factor 3 - Patient Transfer (F3) 5 items (54-58); Factor 
4 - Medication Administration (F4) 5 items (15,16, 18-20); Factor 5-Communication (F5) 5 items (78-80,82,84); Factor 6 - Infections (F6) 4 items (67-70); Factor 7 - Care Practices (F7) 3 items (1-3) (Table 2 and Table 3). The total score range of the scale was 36-180. The scores close to 180 from 108 on the scale indicated that the student nurses were behaving in a controlled or cautious manner with respect to medical errors, while the scores close to 36 from 108 demonstrated that the student nurses might not be in control of medical errors. In order to be able to make a comparison, when divided by the number of items, these scores were found between 1 and 5 in terms of the sum scale and subscale levels. Accordingly, the scale scores were evaluated.

\section{DISCUSSION}

In institutions, timely detection of medical errors/ malpractices is important in order to identify problem areas by uncovering their causes and making measurements and to determine proposals for their solutions. In addition, measurements are necessary to make corrective initiatives by comparing the old and new results, to prevent the reoccurrence and to determine the progress. It is also proposed to examine the attitudes and behavior of patients and the other people involved in the health service provision besides these technical measures, in terms of their awareness level about patient safety so as to ensure patient safety, reduce medical errors, and eliminate or predict adverse conditions $(33,34)$. Additionally, the collection and measurement of the data through a measurement tool that will be able to make valid, accurate and consistent measurements are a necessity for the results to be valuable. When the measurement tools regarding the detection of the individual malpractices/ medical errors of student nurses or the carefulness of students about medical malpractice were investigated, it was seen that in some studies a survey $(15,28,29)$ or qualitative studies $(35)$ were performed, and in a study the content validity of a measurement tool was done (12) but the number of validity and reliability studies was not sufficient. To fill this gap in the literature, there was a need to develop a valid and reliable tool which could guide to determine whether student nurses were careful about medical errors or whether they were making safe patient applications, in which areas they were making more errors, and to take precautions against risky areas, so a MES was tried to be developed for student nurses. In this respect, while face, content, and construct validity studies were performed for the validity of MES, internal consistency tests and item-total correlation analysis that is also a validity test and test/ re-test method called as a stability analysis were done for the reliability of the study.

The reliability is defined as the degree to which a scale measures a desired property in a consistent and stable manner, while the validity is to what extent a scale measures a desired property or whether it is appropriate for the property to be measured $(36,37)$. However, if a test is not valid, then there is no point in discussing its reliability. For this reason, validity is more important than reliability (37).

In this study, firstly, the face and content validity of MES were tried to be ensured. Although face validity has not been performed for a long time since it is indeterminate and subjective, some authors state that face validity is different from the content/scope, so it should be carried out (32). The face validity is used to determine that a tool is in appearance that includes the concept investigated. $(38,39)$. It takes the opinions of the researcher himself, then his close circle of friends, and the other people involved in the pilot study as to whether a scale measures what has been searched. In this process, it is necessary to ensure the conformity of the statements to the purpose and the education, culture and knowledge levels of the target group should not be forced. In addition, the readability, clarity and length analysis of the terms in the scale are performed (32). In this study, the researchers took three student nurses within the scope of face validity. Moreover, the face and content validity of the scale were performed together and the experts were requested to evaluate the face validity of each item in the scale. As a result, 6 incomprehensible, hard-to-read, and long items were rearranged and shortened to be more comprehensible.

The content validity of the scale was tested by Lawshe technique. In this technique, it is recommended that at least 5 and at most 40 experts should be consulted (31). In this study, 15 experts were consulted and 9 items were excluded from the draft scale consisting of 7 sub-scales. The Content Validity Index (CVI) of the scale, formed by 85 items, was 0.82 . This value indicated that the content of the scale was acceptable or that the scale items represented a conceptual main structure for medical malpractices that students might make, because a value of 0.80 or higher for the CVI is considered as an acceptable criterion $(12,40)$.

After the face and content validity, the construct validity of the scale was tested. The exploratory and confirmatory factor analyses were carried out for the construct validity, which identifies the theory or features, or theoretical structures that a scale measures $(36,37,39)$. Factor analysis is a statistical approach that analyses the relationship between a large numbers of variables and explains these variables in terms of common fundamental dimensions (41). In order to be able to perform a factor analysis, there must be a significant correlation between the variables (41). The Bartlett test examines whether there is a sufficient correlation between the variables. The $p$ value of this test is expected to be lower than the significance level of 0.05 . This result shows that there is a sufficient level of correlation between the variables for factor analysis (41). KMO value showing whether the selected sample is sufficient for factor analysis was above expected limit with 0.93 in this 85 -item scale and the Bartlett test was significant at an advanced level. If the value of $\mathrm{KMO}$ is bigger than 0.50 , it is an indication that factor analysis can be carried out. As in our study findings, it is considered perfect if the KMO is higher than $0.90(36,41,42)$. The question group's overall agreement with the KMO is measured by 
factor analysis while each item/ question is measured by anti-image correlation and this value should not be less than 0.50 . If this value is less than 0.50 , it is recommended to exclude this item from the analysis $(32,36,42)$. As for Hair et al., (2010) this value must be above 0.7. The AntiImage Correlation values of the draft scale in this study were over 0.83 . These results showed that factor analysis could be performed. Afterwards, an analysis of the rotated basic components was carried out for exploratory factor analysis. After 7 repeated analyses, 49 items with a load value under 0.45 were removed from the scale. The factor load value of 0.45 or higher is considered as a good criterion for selection $(42,43)$. In this respect, the scale was formed with 36 items and consisted of 7 sub-scales under the title of 'falling, blood and blood products transfusion, patient transfer, medication administration, communication, infection and care practices'. In the Scree plot, the plateau was formed after the seventh point to confirm these 7 subscales (16). The total variance of the scale was $62.5 \%$ and this value, which was explained by seven sub-dimensions. Accordingly, $37.5 \%$ of the scale could not be explained. However, the total variance of the scale is slightly higher than the desired level of variance (60\%). Even for some researchers, the minimum variance explanation ratio is $50 \%(36)$.

After EFA, confirmatory factor analysis (CFA) was performed to confirm the structure. CFA is a method of analysis that shows whether a previously defined or constrained structure is verified as a model (16) or it means the verification of the theoretical structure or model $(16,32)$. CFA is actually used to test the researcher's theorem (44), that is, the researcher must theoretically know what the scale questions measure. But doing this with EFA and verifying it with CFA is a common practice. In other words, the items and subscales determined by performing EFA are regarded as a model and they are tested with CFA to make sure they are correct (44) In addition to this, compared with EFA, CFA is a stronger analysis method because it gives theoretically more reliable information about the validity of the model and factorial structure. In CFA, it is tried to prove that the observed and determined variables, based on the theoretical information, are related to the hidden factors and these hidden factors are related to each other. All assumptions about relationships in CFA are based on the previous research findings and theoretical knowledge. In other words, CFA is applied with the aim of testing and verifying the theoretical information. In this study, in contrast to EFA, the variables/ scale items were previously assigned/ placed in certain factors (32).

It was seen that $t$ test values in CFA of MES were meaningful and no item was meaningless. For this reason, no item was excluded from MES (44). After this process, the goodness-offit tests were examined in CFA to evaluate the validity of the model. There are a wide variety of fit tests in the literature, but there is no exact consensus on which of these fit tests will be regarded as the standard (44). Some of fit tests are chi-square goodness, chi-square/degree of freedom, RMSEA, CFI, NFI, NNFI. Among them chi-square (chi-square goodness $\left.=\chi^{2}\right)$ is the most commonly used one $(44,45)$. In the chi-square test, it is expected that the agreement between the data and the model is perfect, or the value obtained is close to zero and the value of $p$ is not significant. Therefore, the large chi-square values obtained indicate how bad the agreement is (16). Since the chi-square value is influenced by the sample size, the value obtained by dividing the chisquare value by the degree of freedom is taken into account $(16,44)$. For our analysis, the chi-square/degree of freedom $\left(x^{2} / d f\right)$ value was 3.01. This value showed that the scale items were in good agreement with the subscales because the chi-square/freedom value which is 3 and below in the large samples corresponds to a good agreement $(16,41,46)$ and if it is 5 and below corresponds to acceptable agreement $(16,44,47)$. In addition, if the sample size is 200 or smaller, it causes the chi-squared value to shrink and improves the agreement of the model (16). However, although the sample size was more than 200 in this study, the chi-square index showed good agreement. RMSEA value of MES was 0.055 which showed good agreement. The Root Mean Square Error of Approximation (RMSEA), one of the decentralized indexes, is a test used to detect population covariance in decentralized chi square distribution. RMSEA has a value between 0 and 1 ; a value which is less than 0.5 and 0.8 indicates a perfect and good agreement respectively $(16,44,47)$. Other important fit tests are CFI, NFI and NNFI. Comparative Fit Index, one of the comparative fit indexes Comperative Fit Index (CFI) gives the difference between the null model and the established model, assuming there is no relationship between the variables. It compares the covariance matrix produced by the model which predicts no relation between hidden variables and the covariance matrix produced by the proposed structural equation model. CFI value is expected to be between 0 and 1 , and CFI is considered perfect and good or acceptable if it is higher than 0.95 and 0.90 respectively $(16,44,47)$. In this study, the fact that the CFI value explained in the study was 0.97 indicated that the agreement was perfect fit.

As for Normed Fit Index (NFI), it is similar to CFI in terms of its comparative models, but it makes comparisons without the obligation to comply with the assumptions/ quantiles required by the chi square distribution, the model is estimated by comparing the chi-square value of the independent model with the chi-square value of the model. Non-Normed Fit Index (NNFI) is calculated by adding the degree of freedom to the NFI value in small samples. It is similar to NFI but gives a value considering model complexity (16). Similar to CFI, NFI and NNFI have also a value of $0-1$. A value close to 1 indicates perfect agreement while it means an inconsistency when it is close to $0(16,41)$. However, it is expected that both values will be 0.90 and over, which is a good agreement (16). In this study, the NFI value is 0.96 , the NNFI value is 0.97 , or in other words, these values have a good fit. As a result, when the coefficients, showing the relationship between the observed variables and the factors of the model showing the factorial structure of the scale, were examined, it was concluded that all the coefficients were sufficient. When the fit indexs calculated with CFA were taken into account, it 
was decided that the previously determined structure of the scale provided overall agreement with the aggregated data.

After the factor analysis, internal consistency and item discrimination process were carried out. According to the difference between the item average scores of the upper and lower \%27 quartile groups for the internal consistency and item discrimination power, the distinguishing level of the items in the scale was significant or the upper and lower groups of the items were well distinguished. In other words, the validity of the scale items was high, or it can be said that the student nurses distinguished their behaviors related to medical malpractices at a good level and they measured the same behavior. Significant differences between the groups are also considered as a sign of the internal consistency of the test (43).

After this process, the internal consistency was examined to test the reliability and homogeneity of MES, which was formed with 36 items. Internal consistency investigates whether items measure a particular conceptual structure consistently by using a single measurement tool and a single session (32). In another definition, it is the correlation of item scores forming a test with the score obtained from the whole test (37). The Cronbach Alpha, Spearman Brown, and Gutmann values, which show the internal consistency of the MES, were 0.70 and more or close to 1 . In addition, the Cronbach Alpha value at the subscale level was between 0.71 and 0.89 . The higher these values are, the more the items on the scale are consistent with each other and consist of the same items questioning the same characteristics $(32,48)$. A value of 0.70 or higher in the internal consistency coefficients is generally regarded as sufficient for the reliability of test scores $(42,43)$.

Item-total correlation explains the relationship between the scores from the test items and the total score of the test. If the relationship between the scores obtained from an item and the whole scale shows a positive correlation and a "sufficiently high" correlation, then that item is discriminatory or it is assumed that this item simulates similar behavior and is included in the scale $(43,48)$. The item-total correlation values of the 36 -item scale were over 0.36 . When the itemtotal correlation is interpreted, some limit values are taken as criteria. Correlation value should be 0.30 and above, and these items distinguish the individuals at a good level (32, 43).The high correlation values indicated that all scales were in the same structure.

Another test which is used to examine the reliability of the scales is the test-retest. The same form or scale for this test is administered to the same individuals twice under the same conditions but at different times (37). Test-retesting shows whether the measured characteristic of a test has changed according to the elapsed time, or how steady the test has measured over time, or whether similar responses have been reached $(17,48)$ According to the test-retest results in this study, it was seen that MES was stable or consistent in pre and post-administrations at different times and that the scale is reliable in terms of continuity coefficient.

\section{CONCLUSION}

In this study which was conducted to find out whether nursing students were careful about medical malpractices or whether they made any medical errors, the face validity was provided by analyzing the clarity of each item and the length of the statements in the MES. For the content validity, it was determined that the content validity index was close to one or higher, or that the items in the draft scale were aimed at evaluating the attitudes and behaviors of the student nurses regarding medical errors/medical malpractices. For the explanatory factor analysis, through KMO, anti-image correlation test and Barlett test, it was determined that the sample selected for the entire question group was appropriate, each question/ item was appropriate for the factor analysis with, and there was a relation between the variables respectively. As a result of the analysis of the basic components, the scale was formed with 36 items after the rotation and 7 subscales were found as Falling, Blood and Blood Transfusion, Patient Transfer, Medication Administration, Communication, Infections, Care Practices. The variance ratio explained by these 7 sub-dimensions is practically acceptable. In addition, the structure/ model of this scale which was formed or determined by the explanatory factor analysis and consisted of these seven dimensions was confirmed by the confirmatory factor analysis or it was determined that overall agreement was generally good fit according to the results of the confirmatory factor analysis fit indices. Besides, the difference between the upper and lower $27 \%$ quartile groups was meaningful and the results of internal consistency analysis were high. All these results showed that the scale was valid. After the reliability analysis conducted following the validity analyzes, the fact that the Cronbach Alpha, Spearman Brown and Gutmann values of the scale were 0.70 , the item total correlation values were above 0.30 and there was no difference between the testretest results which showed time invariance revealed that 36-item scale was consistent and reliable.

In this respect, this scale can be used to accurately and consistently measure whether the student nurses are careful with regard to malpractices or whether they perform medical errors/ medical malpractices, in which areas they have problems, and where they need to be improved. In the areas where students are likely to make mistakes, the necessary precautions can be taken to prevent them. In addition, this study may be a guide or resource for further scale studies and may provide an opportunity to compare it with the previous scale studies. Besides, retesting the factor analysis of this scale in other samples and retesting its structure by administrating it concurrently along with similar scales could also enhance its validity.

Financial Disclosure: This study is supported by TUBITAK in September 26, 2014. 


\section{REFERENCES}

[1] Vural F, Çiftçi S, Fil Ş, Aydın A, Vural B. Sağıı çalışanlarının hasta güvenliği iklimi algıları ve tıbbı hataların raporlanmasını ACU Sağlık Bil Derg 2014; 5 (2): 152-157 (Turkish).

[2] Karaca A, Arslan H. Hemşirelik hizmetlerinde hasta güvenliği kültürünün değerlendirilmesine yönelik bir çalışma. SHYD 2014; 1(1): 9-18 (Turkish).

[3] Alcan Z, Tekin ED, Civil Özbudak S. Hasta Güvenliği. İstanbul: Nobel Tip Kitabevleri; 2012 (Turkish).

[4] WHO. Patient Safety Curriculum Guide for Medical Schools. France: WHO Press; 2009.

[5] WHO. Patient Safety Curriculum Guide. Multi-professional Edition. Malta: WHO Press; 2011.

[6] Kuğuoğlu S, Çövener Ç, Kürtüncü Tanır M, Aktaş E. İlaç uygulamalarında hemşirenin mesleki ve yasal sorumluluğu. Maltepe Üniversitesi Hemşirelik Bilim ve Sanatı e-Dergisi 2009; 2(2): 86-93 (Turkish).

[7] Güleç D, İntepeler şS. Tıbbi hatalarda tutum ölçeğinin geliştirilmesi. Hemşirelikte Araştırma Geliştirme Dergisi 2013; 15 (3): 26-41 (Turkish).

[8] Akgün S, Al-Assaf AF. Sağlık kuruluşlarında hasta güvenliği kültürünü nasıl oluşturabiliriz? SD 2007; 3: 42-47 (Turkish).

[9] Rodrigue CH, Seoane L, Gala RB, Piazza J, Amedee RG. Developing a practical and sustainable faculty development program with a focus on teaching quality improvement and patient safety: An Alliance for Independent Academic Medical Centers National Initiative III Project. Ochsner J 2012; 12 (4): 338-343.

[10] Mira JJ, Navarro IM, Guilabert M, Poblete R, Franco AL, Jimenez P, Aquino M, Fernandez-Trujilo FJ, Lorenzo S, Vitaller J, Diaz de Velle Y, Aibar C, Aranaz JM, De Pedro JA. A Spanish-language patient safety questionnaire to measure medical and nursing students' attitudes and knowledge. Rev. Panam Salud Publica 2015; 38 (2): 110-119.

[11] Vaismoradi M, Salsali M, Marck P. Patient safety: Nursing students' perspectives and the role of nursing education to provide safe care. Int Nurs Rev 2011; 58 (4): 434-442.

[12] Tabbassum N, Allana S, Daeed T, Dias JM. Content validity of a tool measuring medication errors. Journal of the College of Physicians and Surgeons Pakistan 2015; 25 (8): 623-634.

[13] Mansour M. Factor analysis of nursing students' perception of patient safety education. Nurse Educ Today. 2015; 35(1): 3237.

[14] Wolf ZR, Hicks R, Serembus JF. Characteristics of medication errors made by students during the administration phase: $A$ descriptive study. J Prof Nurs. 2006; 22 (1): 39-51.

[15] Cebeci F, Karazeybek E, Sucu G, Kahveci R. Nursing students' medication errors and their opinions on the reasons of errors: A cross-sectional survey. J Pak Med Assoc 2015; 65 (5): 457 462.

[16] Çokluk Ö, Şekercioğlu G, Büyüköztürk Ş. Sosyal Bilimler İçin Çok Değişkenli İstatistik SPSS ve LISREL Uygulamaları 14. Basım. Ankara: Pegem Akademi; 2014 (Turkish).

[17] Sims RL. Bivariate data analysis: A practical guide. Huntington. NY: Nova Publishers, Inc; 2000.

[18] Maddox P, Wakefield M, Bull J. Patient safety and the need for professional and educational change. Nursing Outlook 2001; 49(1): 8-13.
[19] Aiken L, Clarke SP, Sloane D, Sochalski J, Silber JH. Hospital nurse staffing and patient mortality, nurse burnout, and job dissatisfaction. JAMA 2002; 288: (16), 1987-1993.

[20] Gündoğmuş ÜN, Kurtaş Ö, Boz H, Biçer Ü, Çolak B. The function of experts in determining defects and defect rates. J of Forensic Sci 2002; 1: 63-67.

[21] Mayo AM, Duncan D. Nurses' perceptions of medication errors: What we need to know for patient safety. J of Nurs Care Qual 2004; 19 (3): 209-217.

[22] Temel M. Sağlık personelini ilgilendiren önemli bir konu: Malpraktis. Hemşirelik Forum Dergisi 2005; 3 (1): 84-90 (Turkish).

[23] Ertem G, Oksel E, Akbıyık A. Hatalı tıbbi uygulamalar (Malpraktis) ile ilgili retrospektif bir inceleme. Dirim Tıp Gazetesi 2009; 84 (1): 1-10 (Turkish).

[24] Zencirci DA. Hemşirelik ve Hatalı Tıbbi Uygulamalar. Hemşirelikte Araştırma Geliştirme Dergisi 2010; 1 (7): 67-74 (Turkish).

[25] Özata M, Aslan Ş. The Effect of Nursing and Midwifery Students to Patient Safety. H. Uluslararası Sağlıkta Performans Kongresi Bildiri Kitabı 2. Editor: Kırılmaz H. Türkiye Sağlık Bakanlığı Performans ve Kalite Kongresi; Ankara; 2009. s.60 (Turkish).

[26] Altunkan H. Hemşirelik Hizmeti Sunan Sağlık Personelinde Malpraktis: Konya Örneği. Selçuk Üniversitesi. Sağlık Bilimleri Enstitüsü, Yüksek Lisans Tezi. 2009 (Turkish).

[27] ICN. Nursing Matters; medication errors, fact sheets. Geneva, Switzerland: International Council of Nurses. 2009.

[28] Ayık G, Özsoy S, Çetinkaya A. Hemşirelik öğrencilerinin ilaç uygulama hataları. FNJN 2010; 18 (3): 136-143 (Turkish).

[29] Bodur S, Filiz E, Çimen A, Kapçı C. Ebelik ve hemşirelik son sınıf öğrencilerinin hasta güvenliği ve tıbbi hatalar konusundaki tutumu. Genel Tip Derg 2012; 22 (2): 37-42 (Turkish).

[30] Alemdar DK, Aktaş YY. Medical error types and causes made by nurses in Turkey. TAF Prev Med Bull 2013; 12 (3): 307-314.

[31] Lawshe $\mathrm{CH}$. A quantitative approach to content validity. Pers Psychol 1975; 28 (4): 563-575.

[32] Şencan H. Reliability and validity of social and behavioral measures. Ankara: Seçkin Publishing; 2005. pp. 107, $384,724,725,743,752$.

[33] Baykal Ü, Şahin NH, Altuntaş S. Hasta güvenliği tutum ölçeği'nin Türkçe'ye uyarlanması. HEAD 2010; 7(1): 39-45 (Turkish).

[34] Tak B. Establishing patient safety systems as the main component of quality of care services: a roadmap for hospitals, health performance and quality review: A roadmap for hospitals. Health Performance and Quality Review 2010; 1: 72-113.

[35] Reid-Searl K, Moxham L, Happell B. Enhancing patient safety: The importance of direct supervision for avoiding medication errors and near misses by undergraduate nursing students. Int J Nurs Prac 2010; 16 (3): 225-232.

[36] Altunışık R, Çoşkun R, Bayraktaroğlu S, Yıldırım E. Sosyal Bilimlerde Araştırma Yöntemleri. 7. Baskı. Sakarya: Sakarya Yayıncılık; 2012 (Turkish).

[37] Demircioğlu G. Geçerlilik ve Güvenirlik. Ölçme ve Değerlendirme. Ankara: Pegem Akademi; 2014 (Turkish).

[38] Erefe i. Veri Toplama Araçlarının Niteliği. Hemşirelikte Araştırma. Ankara: Odak Ofset; 2002 (Turkish).

[39] Fawcett AL. Principles of assessment and outcome measurement for occupational therapist and physiotherapist: 
Theory, skills and application. North Yorkshire: John Wiley \& Sons, Ltd; 2007.

[40] Yurdagül H. Ölçek geliştirme çalışmalarında kapsam geçerliliği için kapsam geçerlilik indekslerinin kullanılması. XVI. Ulusal Eğitim Bilimleri Kongresi. 28-30 Eylül 2005; Pamukkale Üniversitesi Eğitim Fakültesi, Denizli: 2005 (Turkish).

[41] Hair JF, Black WC, Barry JB, Rolph EA. Multivariate data analysis (7th Edition). USA: Pearson Prentice Hall; 2010.

[42] Sipahi B, Yurtkoru ES, Cinko M. Data analysis with SPSS in social sciences, İstanbul: Beta Printing Publishing Distribution A.Ş; 2008 (Turkish).

[43] Büyüköztürk S. Sosyal Bilimler için Veri Analizi El Kitabı. 22. Basım. Ankara: Pegem Yayıncılık; 2016 (Turkish).
[44] Çapık C. Geçerlilik ve güvenirlik çalışmalarında doğrulayıcı faktör analizinin kullanımı. Anadolu Hem Sağ Bil Derg 2014; 17(3): 196-205 (Turkish).

[45] Munro BH. Statistical Methods for Health Care Research. Philadelphia: Lippincott Willams \& Wilkins; 2005.

[46] Kline RB. Principles and Practice of Structural Equation Modeling. (Second Edition). NY: Guilford Publications. Inc; 2005.

[47] Hooper D, Coughlan J, Mullen MR. Structural equation modelling: guidelines for determining model fit. Electronic Journal of Business Research Methods 2008; 6 (1): 53-60.

[48] Erkuş A. Psikometri. (Psychometry). Ankara: Türk Psikologlar Derneği Yayınları; 2003 (Turkish). 